\title{
Transparansi Pengelolaan Masjid dengan Laporan Keuangan Berdasarkan Pernyataan Standar Akuntansi Keuangan (PSAK 45)
}

\author{
Wiwin Kurniasari \\ STAIN Salatiga \\ E-mail: wiwinkurniasari@yahoo.com
}

\begin{abstract}
This article describes about the financial management of the mosque, which is one major factor in maintaining the survival and prosperity of the mosque. Good financial management of the mosque, also requires accurate financial reporting systems, especially relating to: 1) the circumstances and conditions of pilgrims, 2) the circumstances and financial condition of the property and the mosque and, 3) other information required in connection with the interests of the mosque. It aims to accountability to the board and the mosque.

In order to apply the principle of openness (transparency) and accountability to the community, the management of an organizational entity in this public space mosques need to make corrections administration, including the publication of consolidated financial accountability. The growing demands on the implementation of accountability in this mosque, it will increase the need for transparency of financial information. This financial information serves as a basic consideration in the decision making process. Therefore we need the financial management of the mosque is based on the Statement of Financial Accounting Standards (PSAK) No. 45 requires accounting in organizations non-profit (in this case is a mosque) using the accrual method, which consists of statements of financial position, activity reports, cash flow statement and notes to the financial statements (IAI 2007).
\end{abstract}

Keywords: transparency, statements of financial position, cash flow statement 


\section{Pendahuluan}

Rasulullah Muhammad SAW pun telah mencontohkan dalam membina dan mengelola seluruh keperluan masyarakat, baik di bidang ekonomi, politik, sosial kemasyarakatan, pendidikan, angkatan bersenjata, dan lain sebagainya melalui masjid. Kuncinya pada pengelolaan masjidnya. Masjid Nabawi oleh Rasulullah SAW difungsikan sebagai (1) pusat ibadah, (2) pusat pendidikan dan pengajaran, (3) pusat informasi Islam, (4) pusat pengkajian dan penyelesaian problematika umat dalam aspek ekonomi, sosial, politik, dan lain-lain. Masih banyak fungsi masjid yang lain. Namun yang jelas pada zaman Rasulullah, masjid dijadikan oleh Beliau sebagai pusat peradaban. Pusat sumber inspirasi dalam mengembangkan syiar dan kemajuan ideologinya. Rasulullah SAW berhasil membina masyarakatnya meskipun komposisi struktur masyarakat yang ada ternyata masyarakat dengan multi ras, multi etnis dan multi agama. Akhirnya, masyarakat bentukan Rasulullah menjadi masyarakat yang disegani dan dikagumi baik lawan maupun kawan dan menjadi pemimpin di dunia pada masanya.

Upaya agar lembaga masjid dapat berfungsi seperti yang diharapkan, yakni sebagai pusat ibadah, pemberdayaan dan persatuan umat dalam rangka meningkatkan keimanan, ketaqwaan, akhlak mulia, kecerdasan umat dan tercapainya masyarakat adil dan makmur yang diridhai Allah s.w.t. Lebih spesifik dapat dikatakan: Hal-hal apa dan bagaimana kita membuat masjid, jamaah sistem, sumber dana dan penggunaannya, dan kegiatannya sehingga masjid ini dapat menjadi pusat kegiatan umat yang dapat menciptakan masyarakat sekelilingnya menjadi masyarakat yang baik, sejahtera, rukun, damai dalam siraman rahmat Allah s.w.t. sebagaimana digambarkan dalam Alquran :

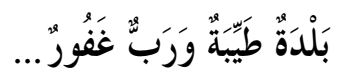

Artinya: "Negeri yang baik dan Tuhan yang Maha Pengampun." (QS. Saba': 15)

Masjid merupakan salah satu bentuk organisasi nirlaba (non-profit oriented). Masjid sebagai sarana peribadatan dan kegiatan umat tentunya 
memerlukan sistem pelaporan keuangan yang efektif. Hal ini dikarenakan masjid juga memerlukan informasi yang dapat menunjang kegiatan peribadatan, kegiatan keagamaan, termasuk aktivitas perawatan dan pemeliharaan masjid. Selain itu, para pengelola masjid (takmir) juga memerlukan sistem pelaporan keuangan masjid yang akurat khususnya yang berhubungan dengan; 1) keadaan dan kondisi jamaah, 2) keadaan dan kondisi harta kekayaan dan keuangan masjid dan, 3) informasi lain yang diperlukan sehubungan dengan kepentingan masjid. Hal ini bertujuan untuk pertanggungjawaban kepada para pengurus dan jamaah masjid. Pengelolaan keuangan masjid yang baik, juga merupakan salah satu faktor utama dalam upaya menjaga kelangsungan hidup dan memakmurkan masjid. Hal ini dikarenakan, masjid juga memerlukan ketersediaan dana yang tidak sedikit setiap bulannya. Dana-dana tersebut diperlukan untuk mendukung kegiatan peribadatan, keagamaan, pengadaan sarana dan prasarana, dan pengembangan masjid. Ini merupakan tanggung jawab para pengurus masjid (takmir) untuk memikirkan, mencari, dan mengumpulkan dana untuk kepentingan masjid.

Populasi masjid dan umat muslim di Indonesia sangat banyak. Kepastian dana mengalir pun selalu ada. Namun, seringkali takmir masjid sebagai pengelola tidak mengetahui persis gambaran pengalokasian dana. Bisa jadi dianggap, kalau ada kegiatan, uang datang cepat. Uang yang ada dialokasikan untuk kegiatan. Tapi, tidak ada gambaran sejak awal mau dikelola seperti apa uang itu. Oleh karena itu, harus ada alternatif agar pengelolaan keuangan masjid bisa berjalan efektif yaitu melalui proses identifikasi aktivitas, sumber-sumber penerimaan, dan penyajian laporan keuangan sesuai dengan anggaran berdasarkan aktivitas.

Setiap masjid tentu memiliki aktivitas yang berbeda tergantung sumber daya, karakter masing-masing masjid dan permasalahannya. Diawali dari pengidentifikasian tersebut, nantinya akan muncul sumber dana. Lalu diikuti dengan rencana penganggaran berdasarkan aktivitas yang sudah direncanakan. Tidak hanya sekedar pengelolaan rutinitas penyelenggaraan ibadah dalam hal kebersihan dan perlengkapan ibadah, pengelola masjid juga dituntut mengadakan kegiatan-kegiatan keagamaan yang lebih, misalnya aktivitas kajian rohani, pendidikan keagamaan khusus, fasilitas 
kesehatan, dan fasilitas taman atau halaman masjid sebagai ruang serba guna (untuk acara akad nikah), serta lembaga-lembaga pendukung seperti Taman Pendidikan Alquran, panitia zakat infaq dan sedekah, ikatan remaja masjid, peringatan hari besar islam, kunjungan ke masjid-masjid, manasik haji, out bound, tour santri, marawis, dan nasyid, donasi, atau lainnya. Bahkan pada masjid-masjid yang sudah besar dalam pengelolaannya yang sudah mengarah pada pengelolaan unit bisnis tertentu serta semakin kompleknya unit bisnis yang dikelola maka penyajian laporan keuangan akan menjadi suatu keharusan. Pada akhirnya laporan keuangan tersebut akan dipublikasikan secara transparansi, sehingga masyarakat akan lebih tenang dan percaya ketika menyumbangkan uangnya.

Kondisi yang demikian semakin menuntut pihak pengelola untuk lebih menjaga kepercayaan publik atas keandalan pengelolaan masjid. Organisasi atau yayasan yang mengelola masjid pada akhirnya memiliki kewajiban mempublikasikan kinerjanya dalam bentuk laporan keuangan yang secara tersurat mengandung pula rincian kegiatan yang telah dilakukan masjid tersebut. Kemampuan takmir masjid untuk terus memberikan jasa dikomunikasikan melalui laporan posisi keuangan yang menyediakan informasi mengenai aktiva,kewajiban, aktiva bersih, dan informasi mengenai hubungan di antara unsur-unsur tersebut. Laporan ini harus menyajikan secara terpisah aktiva bersih baik yang terikat maupun yang tidak terikat. Ikatan Akuntan Indonesia dalam perannya sebagai pembentuk standar akuntansi keuangan secara tertulis telah menerbitkan PSAK 45 yang mengatur tentang pelaporan keuangan organisasi nirlaba.

Masjid merupakan salah satu bentuk organisasi nirlaba. Pada organisasi yang tidak beriorientasi ke profit, ketergantungan pada donatur cukup tinggi, sehingga kepastian dana menjadi pertanyaan besar. Namun, di sisi lain, keikhlasan dari para donatur dan kepercayaan mereka lah yang menjadi nilai tambah bagi para organisasi sektor publik. Kepercayaan itulah yang dapat menjadikan sumber daya atau uang menjadi mengalir dengan pasti ke dalam organisasi. Kepercayaan donatur inilah yang perlu dipelihara, bahkan ditingkatkan jika organisasi menginginkan kepastian serta peningkatan arus kas masuk. Bagaimana agar kepercayaan publik dapat meningkat dan senang mendermakan (mempercayakan) dananya kepada organisasi? Salah satu 
caranya adalah dengan menunjukkan ketercapaian organsisasi kepada mereka.

Selama ini akuntansi sektor publik khususnya nirlaba seperti yayasan dan masjid belum banyak tersentuh. Akuntansi lebih banyak merambah sektor profit oriented padahal organisasi non profit oriented merupakan organisasi yang sumber dananya diperoleh dari banyak orang yang mempercayakan uangnya dengan ikhlas. Tapi apakah ini disalurkan dengan benar? Inilah yang ingin diketahui masyarakat. Karena itulah, justru organisasi nirlaba semacam ini jauh lebih diprioritaskan pertanggungjawaban informasinya karena menyangkut kepentingan elemen individu yang lebih banyak. Salah satu bentuk pertanggungjawaban itu adalah diperlukannya sebuah akuntabilitas dan transparansi tentang pengelolaan keuangan masjid.

\section{Permasalahan}

Faktor-faktor yang menjadi penghambat penerapan laporan keuangan untuk organisasi non profit (nonlaba/nirlaba) berdasarkan PSAK 45 pada masjid-masjid di antaranya:

a. Kurang efektifnya pengelolaan masjid dalam aspek keuangan yang mengakibatkan beberapa masjid menjadi stagnan dengan kondisi yang cukup memprihatinkan.

b. Fokus pencarian dana masjid lebih diprioritaskan daripada akuntabilitas dana yang telah masuk.

c. Sumber daya manusia untuk bidang akuntansi sangat kurang. Keterbatasan itu terjadi karena yayasan atau organisasi takmir masjid tidak mampu mencari akuntan yang andal maupun tidak adanya upaya untuk pendidikan akuntansi bagi pengurus keuangan masjid.

d. Ada beberapa masjid yang tidak berfungsi dan tidak difungsikan lagi.

e. Persepsi-persepsi yang melemahkan usaha kedua belah pihak baik pengawas maupun pengelola untuk meningkatkan kinerja akuntabilitas keuangan. Misalnya ketika melakukan pembangunan atau renovasi masjid, beberapa masjid melakukan pengumpulan dana sementara ketika masjid sudah selesai dibangun atau direnovasi kurang begitu difungsikan secara optimal. 
f. Masalah koordinasi kebijakan akuntansi antara pencatat keuangan yayasan dengan pencatat keuangan masjid, kurang meratanya informasi kebijakan, dan kendala teknis distribusi.

g. Penggunaan rekening tunggal untuk seluruh aktiva bersih sangat beresiko menyebabkan terjadinya pemindahan dana antara kelompok aktiva bersih sebelum dilakukannya keputusan bersama. Hal ini juga berdampak pada lemahnya proses pengawasan lalu lintas kas.

h. Pencatat keuangan masjid tidak menggunakan PSAK 45, selama ini keuangan masjid dilaporkan masih terbatas pada aliran kas masuk dan kas keluar.

\section{Pembahasan}

Masjid sebagai Organisasi Nirlaba menurut AICPA (American Institute of Certified Public Accountants) dan FASB (Financial Accounting Standards Board) adalah termasuk dalam kategori non profit organization. Sedangkan non profit organization adalah entitas yang memiliki karakterisitik sebagai berikut: (1) sebagian besar sumberdaya organisasi tergantung pada penyedia sumber daya yang tidak mengharapkan timbal balik/return, atau ikhlas menyumbangkan sumberdaya tanpa pamrih; (2)operasional organisasi adalah menyediakan barang atau jasa tetapi tidak bertujuan memperoleh keuntungan; (3) tidak ada ownership interest (kepentingan pemilik) seperti perusahaan bisnis. Pada perusahaan bisnis, perusahaan dimiliki oleh investor (Wilson and Kattelus 2002). Wilson and Kattelus (2002) menyatakan bahwa komunitas agama termasuk dalam independent sector of not-for-profit sector yang bebas dari pajak. Pilihan basis akuntansi untuk organisasi sektor publik ada 4, yaitu: (1)basis kas; (2)basis kas modifikasian; (3)basis akrual dan (4)basis akrual modifikasian. Di Indonesia, praktik akuntansi sektor privat menggunakan metode akrual. Peraturan Pemerintah no. 24 tahun 2005 tentang Standar Akuntansi Pemerintahan, menghendaki dual basis, yaitu untuk pengakuan pendapatan, belanja dan pembiayaan dalam Laporan Realisasi Anggaran menggunakan basis kas, dan pengakuan aktiva, kewajiban dan ekuitas dalam Neraca menggunakan basis akrual. Pernyataan Standar Akuntansi Keuangan (PSAK) No. 45 menghendaki akuntansi di organisasi nonlaba menggunakan metode akrual (IAI 2007). 
Beberapa hasil penelitian menyatakan bahwa praktik akuntansi akrual tidak cocok untuk organisasi sektor publik. Alasan mengapa organisasi nonlaba kurang tepat jika menggunakan metoda akrual adalah: (1) tujuan utama organisasi bukan laba, sehingga pencarian angka laba tidak relevan untuk pengukuran kinerja, (2) struktur financial dan solvency juga tidak relevan digunakan dalam lingkup organisasi sektor publik, (3) akuntansi akrual bukanlah ukuran outcome, (4) akuntansi akrual mempersempit fokus kinerja, semata-mata fokus pada cost of service dan efisiensi (Ma and Matthews 1993; Guthrie and Johnson 1994; Lewis 1995; Guthrie 1998 dalam Nasi and Steccolini 2008: 175-196). Perdebatan mengenai metode akuntansi ini juga diungkapkan oleh Ives, et al. (2009) dalam Diptyana (2009). Basis akrual pada organisasi pemerintahan maupun nonlaba diterapkan ketika mereka melaporkan aktivitas yang bertipe bisnis. Untuk aktivitas yang sifatnya pemerintahan dasar, digunakan basis akuntansi dengan tipe-hibrid, yaitu modified accrual basis of accounting. Dengan basis ini, pengukuran dilakukan hanya untuk arus masuk (inflows) dan arus keluar (outflows) aktiva lancar yang finansial (financial current resources), tidak mengukur seluruh sumberdaya ekonomik. Walaupun demikian, Nasi and Steccolini (2008: 175196) membuktikan bahwa praktik akuntansi berbasis kas dan akuntansi komitmen lebih dapat diterima oleh para CFO (Chief Financial Officer) di organisasi sektor publik.

Tujuan utama laporan keuangan adalah menyediakan informasi yang relevan untuk memenuhi kepentingan para penyumbang, anggota organisasi, kreditur, dan pihak lain yang menyediakan sumber daya bagi organisasi nirlaba. Pihak pengguna laporan keuangan organisasi nirlaba memiliki kepentingan bersama dalam rangka menilai:

a) Jasa yang diberikan oleh organisasi nirlaba dan kemampuannya unt uk terus memberikan jasa tersebut

b) Cara manajer melaksanakan tanggung jawabnya dan aspek lain dari kinerja mereka.

Secara rinci, tujuan laporan keuangan, termasuk catatan atas laporan keuangan, adalah untuk menyajikan informasi mengenai:

a) Jumlah dan sifat aktiva, kewajiban, dan aktiva bersih suatu organisasi. 
b) Pengaruh transaksi, peristiwa dan situasi lainnya yang mengubah nilai dan sifat aktiva bersih.

c) Jenis dan jumlah arus masuk dan arus keluar sumber daya dalam satu periode dan hubungan antara keduanya.

d) Cara suatu organisasi mendapatkan dan membelanjakan kas, memperoleh pinjaman dan melunasi pinjaman, dan faktor lainnya yang berpengaruh pada likuiditasnya.

e) Usaha jasa suatu organisasi.

Setiap laporan keuangan menyediakan informasi yang berbeda, dan informasi dalam suatu laporan keuangan biasanya melengkapi informasi dalam laporan keuangan yang lain.

Manajemen suatu entitas organisasi dalam hal ini ruang publik masjid perlu untuk melakukan pembenahan administrasi, termasuk publikasi pertanggung jawaban laporan keuangan. Semakin besar tuntutan terhadap pelaksanaan akuntabilitas ruang publik dalam hal ini masjid, maka akan memperbesar kebutuhan akan transparansi informasi keuangan. Informasi keuangan ini berfungsi sebagai dasar pertimbangan dalam proses pengambilan keputusan. Tuntutan dari agama dijelaskan oleh surat Al Baqarah ayat 282, yang artinya "hai orang-orang beriman, apabila kamu bermuamalah tidak secara tunai untuk waktu yang ditentukan, hendaklah seorang penulis di antara kami menuliskannya dengan benar. Dan janganlah penulis enggan menulisnya sebagaimana Allah s.w.t. telah mengajarkannya, maka hendaklah ia menulis, dan hendaklah orang yang berutang itu mengimlakkan apa yang ditulis itu, dan hendaklah ia bertakwa kepada Allah s.w.t. Tuhannya, dan janganlah ia mengurangi sedikitpun daripada utangnya. Jika yang berutang itu orang yang lemah akal atau lemah keadaannya atau dia sendiri tidak mampu mengimlakkan, maka hendaklah walinya mengimlakkan dengan jujur."

Muamalah dapat diartikan dengan transaksi, seperti kegiatan jual beli, utang piutang, sewa menyewa, dan sebagainya. Dengan demikian, aktivitas penyerahan dana dari penderma/donatur kepada pengelola dapat disebut dengan transaksi, karena dana tersebut diserahkan dengan maksud tertentu, baik untuk pembangunan masjid, pemeliharaan masjid dan kegiatan-kegiatan 
yang mensejahterakan umat para pengguna masjid, dan dana ini membutuhkan akuntabilitas dari pengelolanya. Al Baqarah 282 tersebut juga dapat dimaknakan pentingnya pencatatan secara double entry, dari sisi penerima dana dan pemberi dana. Alasan kedua dan ketiga relevan dengan tujuan pelaporan keuangan di sektor privat, yakni pelaporan keuangan ditujukan untuk pihak eksternal dan internal organisasi. Sama dengan tujuan di sektor privat, laporan keuangan di organisasi pengelola masjid juga disajikan untuk pengambilan keputusan alokasi sumberdaya, dan menginformasikan perubahan atas sumberdaya.

Menurut Mardiasmo (2002:161), tujuan dan fungsi laporan keuangan sektor publik adalah sebagai berikut: (1) kepatuhan dan pengelolaan (compliance and stewardship), yaitu laporan keuangan digunakan untuk memberikan jaminan kepada pengguna laporan keuangan dan pihak otoritas penguasa bahwa pengelolaan sumber daya telah dilakukan sesuai dengan ketentuan hukum dan peraturan yang telah ditetapkan. (2) akuntabilitas dan pelaporan retrospektif (accountability and retrospective reporting), yaitu laporan keuangan digunakan sebagai bentuk pertanggungjawaban kepada publik. Laporan keuangan digunakan untuk memonitor kinerja dan mengevaluasi manajemen, memberikan dasar untuk mengamati trend antar kurun waktu, pencapaian atas tujuan yang telah ditetapkan, dan membandingkanya dengan kinerja organisasi lain yang sejenis. Laporan keuangan juga memungkinkan pihak luar untuk memperoleh informasi biaya atas barang dan jasa yan diterima, serta memungkinkan bagi mereka untuk menilai efisiensi dan efektivitas penggunaan sumber daya organisasi. (3) perencanaan dan informasi otorisasi (planning and authorization information), yaitu laporan keuangan berfungsi sebagai dasar perencanaan kebijkan dan aktivitas di masa yang akan datang. Laporan keuangan berfungsi untuk memberikan informasi pendukung mengenai otorisasi penggunaan dana. (4) kelangsungan organisasi (viability), yaitu laporan keuangan berfungsi untuk membantu pembaca dalam menentukan apakah suatu organisasi atau unit kerja dapat meneruskan menyediakan barang dan jasa (pelayanan) di masa yang akan datang. (5) hubungan masyarakat (public relation), yaitu laporan keuangan berfungsi untuk memberikan kesempatan kepada organisasi mengemukakan pernyataan atas prestasi yang telah dicapai kepada pemakai, dan masyarakat. 
Laporan keuangan sebagai alat berkomunikasi dengan publik dan pihak yang berkepentingan. (6) sumber fakta dan gambaran (source of fact and figures), yaitu laporan keuangan bertujuan untuk memberikan informasi kepada berbagai kelompok kepentingan yang ingin mengetahui organisasi secara lebih mendalam.

Laporan keuangan sektor publik merupakan representasi terstruktur dari posisi keuangan akibat transaksi yang dilakukan. Indra (2006: 96) menyebutkan tujuan umum pelaporan keuangan sektor publik (dalam hal ini masjid termasuk sebagai sektor publik) adalah menyediakan entitas atas sumber yang dipercayakan dengan: (1) menyediakan informasi mengenai sumber-sumber, alokasi, dan penggunaan sumber daya finansial. (2) menyediakan informasi mengenai bagaimana entitas mendanai aktivitasnya dan memenuhi persyaratan kasnya. (3) menyediakan informasi yang berguna dalam mengevaluasi kemampuan entitas dan perubahan di dalamnya. (4) menyediakan informasi yang menyeluruh yang berguna dalam mengevaluasi kinerja entitas atas hal biaya jasa, efisiensi, dan pencapaian tujuan.

Laporan keuangan tidak hanya dibuat oleh organisasi laba, organisasi nonlaba juga memerlukan laporan keuangan guna mengetahui kegiatan organisasi dalam 1 periode dan kemampuan organisasi dalam memberikan pelayanan dan penyaluran dana dan kegiatan sosial lainnya kepada pihak yang membutuhkan. Masing-masing entitas nirlaba memiliki karakteristik yang unik dan masih perlu dilakukan penyempurnaan berkaitan dengan standarisasi pelaporan keuangannya, oleh karena itu yang disiapkan juga akan disesuaikan dengan karakteristik organisasi namun tetap pada prinsip akuntansi yang berlaku umum (PABU) di Indonesia. Laporan keuangan yang baik adalah laporan keuangan yang terhindar dari salah saji material, mudah dimengerti, dan tentunya harus sesuai dengan Pernyataan Standar Akuntansi Keuangan (PSAK).

Menurut PSAK No. 45 (IAI 2007: 45.4), laporan keuangan organisasi nonlaba terdiri dari laporan posisi keuangan, laporan aktivitas, laporan arus kas, dan catatan atas laporan keuangan. Laporan posisi keuangan menyajikan jumlah masing masing kelompok aktiva bersih berdasarkan ada atau tidaknya pembatasan oleh penyumbang, yaitu: terikat secara permanen, terikat secara temporer, dan tidak terikat. Tujuan laporan posisi keuangan adalah untuk 
menyediakan informasi mengenai aktiva, kewajiban, dan aktiva bersih dan informasi mengenai hubungan di antara unsur-unsur tersebut pada waktu tertentu. Informasi dalam laporan posisi keuangan yang digunakan bersama pengungkapan dan informasi dalam laporan keuangan lainnya, dapat membantu para penyumbang, anggota organisasi, kreditur dan pihak-pihak lain untuk menilai:

a) kemampuan organisasi untuk memberikan jasa secara berkelanjutan

b) likuiditas, fleksibilitas keuangan, kemampuan untuk memenuhi kewajibannya, dan kebutuhan pendanaan eksternal.

Laporan aktivitas difokuskan pada organisasi secara keseluruhan dan menyajikan perubahan jumlah aktiva bersih selama suatu periode. Perubahan aktiva bersih dalam laporan aktivitas tercermin pada aktiva bersih atau ekuitas dalam laporan posisi keuangan. Tujuan utama laporan aktivitas adalah menyediakan informasi mengenai (a) pengaruh transaksi dan peristiwa lain yang mengubah jumlah dan sifat aktiva bersih, (b) hubungan antar transaksi, dan peristiwa lain, dan (c) bagaimana penggunaan sumber daya dalam pelaksanaan berbagai program atau jasa, Informasi dalam laporan aktivitas, yang digunakan bersama dengan pengungkapan informasi dalam laporan keuangan lainnya, dapat membantu para penyumbang, anggota organisasi, kreditur dan pihak lainnya untuk (a) mengevaluasi kinerja dalam suatu periode, (b) menilai upaya, kemampuan, dan kesinambungan organisasi dan memberikan jasa, dan (c) menilai pelaksanaan tanggung jawab dan kinerja manajer Laporan aktivitas mencakup organisasi secara keseluruhan dan menyajikan perubahan jumlah aktiva bersih selama suatu periode. Perubahan aktiva bersih dalam laporan aktivitas tercermin pada aktiva bersih atau ekuitas dalam laporan posisi keuangan.

Tujuan utama laporan arus kas adalah menyajikan informasi mengenai penerimaan dan pengeluaran kas dalam suatu periode. Klasifikasi Penerimaan dan Pengeluaran Kas. Laporan arus kas disajikan sesuai PSAK 2 tentang Laporan Arus Kas dengan tambahan berikut ini: a) Aktivitas pendanaan yang terdiri dari :

1) penerimaan kas dari penyumbang yang penggunaannya dibatasi untuk jangka panjang. 
2) penerimaan kas dari sumbangan dan penghasilan investasib yang penggunaannya dibatasi untuk pemerolehan, pembangunan dan pemeliharaan aktiva tetap, atau peningkatan dana abadi (endowment).

3) bunga dan dividen yang dibatasi penggunaannya untuk jangka panjang.

b) Pengungkapan informasi mengenai aktivitas investasi dan pendanaan nonkas: sumbangan berupa bangunan atau aktiva investasi.

Akun-akun diklasifikasikan berdasarkan aset, pendapatan dan beban yang tidak terikat, terikat temporer, terikat permanen, serta kewajiban. Pembatasan permanen adalah pembatasan penggunaan sumberdaya yang ditetapkan oleh penyumbang agar sumberdaya tersebut dipertahankan secara permanen, tetapi organisasi diijinkan untuk menggunakan sebagian atau semua penghasilan atau manfaat ekonomi lainnya yang berasal dari sumber daya tersebut. Pembatasan temporer adalah pembatasan penggunaan sumberdaya oleh penyumbang yang menetapkan agar sumber daya tersebut dipertahankan sampai dengan periode tertentu atau sampai dengan terpenuhinya keadaaan tertentu. Sumbangan terikat adalah sumber daya yang penggunaannya dibatasi untuk tujuan tertentu oleh penyumbang. Pembatasan tersebut dapat bersifat permanen atau temporer. Sumbangan tidak terikat adalah sumber daya yang penggunaannya tidak dibatasi untuk tujuan tertentu oleh penyumbang (IAI 2007, par. 03 dan 05).

Contoh Laporan Posisi Keuangan 
Masjid XYZ

Laporan Posisi Keuangan

31 Desember 20xx dan 20xy

\begin{tabular}{|c|c|c|c|}
\hline & & $20 x x$ & $20 x y$ \\
\hline \multicolumn{4}{|c|}{ Aktiva: } \\
\hline & Kas dan setara kas & & \\
\hline & Piutang bunga (bagi hasil) & & \\
\hline & Persediaan dan biaya dibayar di muka & & \\
\hline & Piutang lain -lain & & \\
\hline & Investasi lancar & & \\
\hline & $\begin{array}{l}\text { Aktiva terikat untuk investasi dalam } \\
\text { tanah, bangunan, \& peralatan }\end{array}$ & & \\
\hline & Investasi jangka panjang & & \\
\hline & Jumlah aktiva & & \\
\hline \multicolumn{4}{|c|}{ Kewajiban dan Aktiva Bersih : } \\
\hline & Hutang usaha & & \\
\hline & $\begin{array}{l}\text { Pendapatan diterima di muka yang } \\
\text { dapat dikembalikan }\end{array}$ & & \\
\hline & Hutang lain -lain & & \\
\hline & Hutang wesel & & \\
\hline & Kewajiban tahunan & & \\
\hline & Hutang jangka panjang & & \\
\hline & Jumlah Kewajiban & & \\
\hline \multicolumn{4}{|c|}{ Aktiva Bersih : } \\
\hline & Tidak terikat & & \\
\hline & Terikat temporer & & \\
\hline & Terikat permanen & & \\
\hline & Jumlah aktiva bersih & & \\
\hline & $\begin{array}{l}\text { Jumlah Kewajib an dan Aktiva } \\
\text { Bersih }\end{array}$ & & \\
\hline
\end{tabular}

Sumber: IAI 2007:45.16 
Contoh Laporan Aktivitas

Masjid XYZ

Laporan Aktivitas 31 Desember 20xy

\begin{tabular}{|c|c|c|}
\hline \multicolumn{2}{|r|}{ Perubahan Aktiva Bersih Tidak T erikat: } & Rp..... \\
\hline \multicolumn{3}{|c|}{\begin{tabular}{l|l} 
& Pendapatan dan Penghasilan: \\
\end{tabular}} \\
\hline & \begin{tabular}{l|l} 
Sumbangan \\
\end{tabular} & \\
\hline & Jasa layanan & \\
\hline & Penghasilan investasi jangka panjang & \\
\hline & Penghasilan investasi lain $\quad$-lain & \\
\hline & $\begin{array}{l}\text { Penghasilan bersih investasi jangka panjang } \\
\text { belum direalisasi }\end{array}$ & \\
\hline & $\begin{array}{l}\text { Jumlah Pendapatan dan Penghasilan Tidak } \\
\text { terikat }\end{array}$ & \\
\hline \multicolumn{3}{|c|}{ Aktiva Bersih yang Berakhir Pembatasannya } \\
\hline & \begin{tabular}{l|l} 
Pemenuhan progr am pembatasan \\
\end{tabular} & \\
\hline & Pemenuhan pembatasan pemerolehan peralatan & \\
\hline & Berakhirnya pembatasan waktu & \\
\hline & $\begin{array}{l}\text { Jumlah Aktiva Bersih yang Berakhir } \\
\text { Pembatasannya }\end{array}$ & \\
\hline & $\begin{array}{l}\text { Jumlah Pendapatan, Penghasilan, dan } \\
\text { Sumbangan lain }\end{array}$ & \\
\hline \multicolumn{3}{|c|}{ Beban dan Kerugian: } \\
\hline & \begin{tabular}{l|l} 
Program A \\
\end{tabular} & \\
\hline & Program B & \\
\hline & Program C & \\
\hline & Manajemen dan Umum & \\
\hline & Pencarian Dana & \\
\hline & Jumlah Beban & \\
\hline & Kerugian akibat kebakaran & \\
\hline & Jumlah Beban dan Kerugian & \\
\hline & \begin{tabular}{l|l|} 
& Kenaikan Jumlah Aktiva Bersih Tidak Terikat \\
\end{tabular} & \\
\hline \multicolumn{3}{|c|}{ Perubahan Aktiva Bersih Terikat Temporer: } \\
\hline & \begin{tabular}{l|l} 
Sumbangan \\
\end{tabular} & \\
\hline & Penghasilan in vestasi jangka panjang & \\
\hline & $\begin{array}{l}\text { Penghasilan bersih terealisasikan dari investasi } \\
\text { jangka panjang }\end{array}$ & \\
\hline & Kerugian aktuarial untuk kewajiban tahunan & \\
\hline & Aktiva Bersih Terbebaskan dari Pembatasan & \\
\hline & \begin{tabular}{l|l} 
Penurunan aktiva bersih terikat temporer \\
\end{tabular} & \\
\hline \multicolumn{3}{|c|}{ Perubahan Aktiva Bersih Terikat Permanen: } \\
\hline & \begin{tabular}{l|l} 
Sumbangan \\
\end{tabular} & \\
\hline & Penghasilan dari investasi jangka panjang & \\
\hline & $\begin{array}{l}\text { Penghasilan bersih terealisasikan \& belum } \\
\text { terealisasikan dari investasi jangka panjang }\end{array}$ & \\
\hline & \begin{tabular}{|l|l|}
$\begin{array}{l}\text { Kenaikan Jumlah Aktiva Bersih Terikat } \\
\text { Permanen }\end{array}$ \\
\end{tabular} & \\
\hline \multicolumn{3}{|c|}{ Kenaikan Aktiva Bersih } \\
\hline \multicolumn{3}{|c|}{ Aktiva Bersih Pada Awal Tahun } \\
\hline \multicolumn{2}{|c|}{ Aktiva Bersih Pada Akhir Tahun } & \\
\hline
\end{tabular}

Sumber: IAI 2007:45.18 
Contoh Laporan Arus Kas Metode Langsung

Masjid XYZ

Laporan Arus Kas 31 Desember 20xy

\begin{tabular}{|c|c|c|}
\hline \multicolumn{2}{|c|}{ Aliran Kas dari Aktivitas Operasi : } & Rp..... \\
\hline & \multicolumn{2}{|l|}{ Kas dari pendapatan jasa } \\
\hline \multicolumn{3}{|c|}{ Kas da ri penyumbang } \\
\hline \multicolumn{3}{|c|}{ Kas dari piutang lain -lain } \\
\hline \multicolumn{2}{|r|}{ Bunga dan deviden yang diterima } & \\
\hline \multicolumn{2}{|r|}{ Penerimaan lain -lain } & \\
\hline \multicolumn{2}{|r|}{ Bunga yang dibayarkan } & \\
\hline \multicolumn{2}{|r|}{ Kas yang dibayarkan kepada karyawan dan suplier } & \\
\hline \multicolumn{2}{|r|}{ Hutang lain -lain yang dilunasi } & \\
\hline \multicolumn{2}{|r|}{\begin{tabular}{|l|l|} 
Kas bersih yang diterima (digunakan) unt uk aktivitas \\
operasi
\end{tabular}} & \\
\hline \multicolumn{2}{|r|}{ Aliran Kas dari Aktivitas Investasi : } & \\
\hline \multicolumn{2}{|r|}{\begin{tabular}{l|l} 
& Ganti rugi dari asuransi kebakaran \\
\end{tabular}} & \\
\hline \multicolumn{2}{|r|}{ Pembelian peralatan } & \\
\hline \multicolumn{2}{|r|}{ Penerimaan dari penjualan investasi } & \\
\hline \multicolumn{2}{|r|}{ Pembelian investasi } & \\
\hline \multicolumn{2}{|r|}{\begin{tabular}{|l|l|} 
& $\begin{array}{l}\text { Kas bersih yang diterima (digunakan) untuk aktivitas } \\
\text { investasi }\end{array}$ \\
\end{tabular}} & \\
\hline \multicolumn{3}{|c|}{ Aliran Kas dari Aktivitas Pendanaan: } \\
\hline \multicolumn{2}{|r|}{\begin{tabular}{l|l} 
& Penerimaan dari kontribusi berbatas dari: \\
\end{tabular}} & \\
\hline \multicolumn{2}{|r|}{ Investasi dalam endowment } & \\
\hline \multicolumn{2}{|r|}{ Investasi dalam endowment berjangka } & \\
\hline \multicolumn{2}{|r|}{ Investasi bangunan } & \\
\hline \multicolumn{2}{|r|}{ Investasi perjanjian tahunan } & \\
\hline \multicolumn{2}{|r|}{ Aktivitas pendanaan lain: } & \\
\hline \multicolumn{2}{|r|}{ Bunga dan devi den berbatas untuk reinvestasi } & \\
\hline \multicolumn{2}{|r|}{ Pembayaran kewajiban tahunan } & \\
\hline \multicolumn{2}{|r|}{ Pembayaran hutang wesel } & \\
\hline \multicolumn{2}{|r|}{ Pembayaran kewajiban jangka panjang } & \\
\hline \multicolumn{2}{|r|}{\begin{tabular}{|l|l|} 
& $\begin{array}{l}\text { Kas bersih yang diterima (digunakan) untuk aktivitas } \\
\text { pendanaan }\end{array}$ \\
\end{tabular}} & \\
\hline \multicolumn{2}{|r|}{ Kenaikan (Penurunan) bersih dalam kas dan setara kas } & \\
\hline \multicolumn{2}{|r|}{ Kas dan setara kas Pada Awal Tahun } & \\
\hline \multicolumn{2}{|r|}{ Kas dan setara kas $\quad$ Pada A khir Tahun } & \\
\hline $\begin{array}{l}\text { Rek } \\
\text { yan }\end{array}$ & $\begin{array}{l}\text { nsisliasi perubahan dalam aktiva bersih menjadi kas bersih } \\
\text { digunakan untuk aktivitas operasi: }\end{array}$ & \\
\hline & Perubahan dalam aktiva bersih & \\
\hline
\end{tabular}




\begin{tabular}{|c|c|}
\hline & $\begin{array}{l}\text { Penyesuaian untuk rekonsiliasi perubahan dalam aktiva } \\
\text { bersih menjadi kas bersih yang digunakan untuk aktivitas } \\
\text { operasi: }\end{array}$ \\
\hline & Depresiasi \\
\hline & Kerugian akibat kebakaran \\
\hline & Kerugian aktuarial pada kewajiban tahunan \\
\hline & Kenaikan piutang bunga \\
\hline & Penurunan dalam persediaan dan biaya dibayar dimuka \\
\hline & Kenaikan dalam piutang lain $\quad$-lain \\
\hline & Kenaikan dalam hutang dagang \\
\hline & $\begin{array}{l}\text { Penurunan dalam penerimaan di muka yang dapat } \\
\text { dikembalikan }\end{array}$ \\
\hline & Penurunan dalam hutang lain $\quad$-lain \\
\hline & Sumbangan terikat untuk investasi jangka panjang \\
\hline & $\begin{array}{l}\text { Bunga dan deviden terikat untuk investasi jangka } \\
\text { panjang }\end{array}$ \\
\hline & $\begin{array}{l}\text { Penghasilan bersih terealisasikan dan belum } \\
\text { terealisasikan dari investasi jangka panjang }\end{array}$ \\
\hline & \begin{tabular}{l|l} 
Kas bersih yang diterima (digunakan) untuk aktivitas \\
operasi
\end{tabular} \\
\hline \multicolumn{2}{|r|}{ Data tambahan untuk aktivitas investasi dan pendanaan non kas: } \\
\hline & Pera latan yang diterima sebagai hibah \\
\hline & $\begin{array}{l}\text { Pembebasan premi asuransi kematian, nilai kas yang } \\
\text { diserahkan }\end{array}$ \\
\hline
\end{tabular}

Sumber: IAI 2007:45.24

\section{Penutup}

Berdasarkan pengamatan yang telah dilakukan penulis memperlihatkan bahwa penyajian informasi keuangan masjid sebagai bentuk akuntabilitas dan transparansi dilakukan dengan menggunakan dua cara yaitu; 1) diumumkan setiap Jum'at (sebelum khatib naik mimbar) atau bila bulan ramadhan akan diumumkan sebelum shalat isya atau tarawih, dan 2) ditempel di papan informasi masjid. Laporan keuangan masjid sebagai bentuk pertanggungjawaban publik masih terbatas pada metode pembukuan single entry method (metoda pembukuan tunggal). Untuk pencatatan transaksi keuangan masjid, takmir tidak melakukan kegiatan pencatatan (jurnal, buku besar, dll), pengklasifikasian dan pengikhtisaran. Laporan keuangan yang dibuat oleh masjid menggunakan pendekatan anggaran atau akuntansi dana, 
yang melaporkan tentang sumber dan penggunaan dana serta saldo setiap bulannya yang bila disesuaikan dengan standar yang berlaku yaitu PSAK No. 45 menunjukkan bahwa laporan keuangan yang dibuat masih terbatas pada laporan arus kas saja belum berpedoman pada PSAK No. 45 yang terdiri dari laporan posisi keuangan, laporan aktivitas, laporan arus kas, dan catatan atas laporan keuangan.

Saran untuk usaha penerapan Laporan keuangan masjid berdasarkan PSAK 45 secara umum, yaitu:

a. Penyusunan laporan keuangan organisasi dan yayasan pengelola masjid harus berpedoman pada PSAK 45 sebagai pedoman akuntansi yang berlaku umum bagi semua entitas nonlaba (nirlaba) di Indonesia.

b. Dalam pembenahan organisasi masjid, prioritas pencarian dana masuk harus diseimbangkan dengan usaha akuntabilitas laporan keuangan.

c. Hilangkan persepsi buruk yang melemahkan usaha kedua belah pihak.

d. Koordinasi kebijakan akuntansi antara yayasan dengan unit pelaksana takmir masjid harus dilakukan secara efektif.

e. Gunakan rekening kas yang berbeda tergantung sifat keterikatan kas yang diterima untuk menghindari penyalahgunaan pemindahan dana tanpa keputusan otorisator.

f. Diperlukan adanya pelatihan dan pendampingan bagi para pencatat keuangan masjid atau yayasan pengelola masjid.

\section{Daftar Pustaka}

Diptyana, Pepie. 2009. Modul Pelatihan Pencatatan Keuangan dengan Identifikasi Aktivitas Untuk Penganggaran Masjid. Surabaya: STIE Perbanas Surabaya.

Ikatan Akuntan Indonesia. 2008. Standar Akuntansi Keuangan per 1 September 2007. Jakarta: Salemba Empat.

, 2007. Pernyataan Standar Akuntansi Keuangan No. 1. Jakarta: Salemba Empat.

, 2007. Pernyataan Standar Akuntansi Keuangan No. 2. Jakarta:

Salemba Empat.

, 2007. Pernyataan Standar Akuntansi Keuangan No. 45. Jakarta:

Salemba Empat. 
, 2007. Pernyataan Standar Akuntansi Keuangan No. 101. Jakarta: Salemba Empat.

Indra, Bastian. 2008. Akuntansi Sekot Publik. Jakarta: Salemba Empat. Mardiasmo, 2009.Akuntansi Sekot Publik. Yogyakarta: Andi.

Nasi, Greta and Steccolini, Ileana. 2008. Implementation of Accounting Reform. Public Management Review. Vol. 10 Issue 2, 2008.

Wilson, Earl R. and Kattelus, Susan C. 2004. Accounting for Governmental and Nonprofit Entities, 13th Edition. New York : McGraw-Hill. 